\title{
The Challenges of Women Empowerment for Sustainable Development in Nigeria
}

\author{
DR. (Mrs.) Florence Undiyaundeye \\ Department of Early Childhood Care Development Education \\ Federal College of Education, Obudu Cross River State, Nigeria \\ E-mail: atube2001@yahoo.com
}

Doi:10.5901/ajis.2013.v2n11p9

\begin{abstract}
Education is a potent tool in the emancipation and empowerment of women. The greatest single factor which can incredibly improve the status of women in any society is education. It is indispensible that it enables women not only to gain more knowledge about the world but helps her to get status, positive self esteem and self confidence, necessary courage and inner strength to face challenges in life. Apparently it also facilitates them to procure a job and supplement the income of family and achieve social status. Educated women can play an equal role as men in nation building. Therefore, the is no denying fact that education empowers women. In spite of the forceful intervention by international women groups, feminist critics, constitutional guarantees, protecting laws and sincere efforts by the government at all levels through various schemes and programmes to uplift the plight of women, education and women empowerment is still an enigma for variation of reasons. The 2003 and 2005 UNESCO report indicates that literacy among women is only $54 \%$ and Nigeria is still at the risk of not achieving the Education For All (EFA) goals. The growth of women education in the rural areas is still very low. This obviously means that there is still a large number of women folk who are illiterate, weak, backward and exploited. Gender inequality is re-enforced in education which is proved by the high percentage of men who are educated compared to the percentage of their female counterparts. This paper views the reasons for gender inequality in educational system, recommend that women themselves should develop negotiative skills and rise to the challenges of assisting themselves in a competitive society and conclude that there is obvious inequality against the girl child in enrollment, attendance and completion rate in all levels of education in Nigeria especially the northern part due to variety of cultural and religious factors.
\end{abstract}

\section{Introduction}

Education is basic to a person's ability to maximize any opportunity that may arise from development. Education, whether formal or informal constitutes a vital instrument for socio-economic development of any society as well as the upliftement of the individual concerned (Ainabor and Ovkgele, 2007). Education is a human right, an instrument of freedom, democracy, good governance and sustainable human and national development hinges on it. It also aims at elimination of ignorance, poverty disease and the provision of the requisite knowledge for the empowerment needed for full actualization of human potential.

Although the National Policy on Education as well as the 199 constitution of Nigeria emphasize equal right to education by male and females in Nigeria, evidence of gender inequality in access to education abound as women suffer discriminatory practices in the field of education. This menace remains the basic constraint to women in our educational system.

According to Joe (2005) cited in Abiola (2006), the government of Nigeria reported in 2003 that an estimate of 7 million (35\%) of the total number of Nigeria's children of primary school age are not enrolled in primary school. $62 \%$ of the 7 million are girls, about 4.3 million girls are out of school. This estimate reveals that while there is a growing demand for education and explosion of world population, the disparities between the populations of men who have access to education than their female counterparts who do not have are also growing.

\section{Concept of Gender}

Gender as a concept and usage among policy makers, planners and the generality of people in Nigeria, has been appreciably misconstrued. Most times, when the word gender is used, people immediately suppose that reference is being made to women and their affairs and vice versa (Ainabor, Ainabor and Ehimi, 2009). According to Ametefe and 
Ametefe 2007), gender is a social construct that establishes and differentiates status and role between men and women particularly in the way they contribute to, participate in and are rewarded by the economy and most social institutions.

Omatsey (2004) sees gender "as the sense of being a male or female". However, he added that there is a line of demarcation between sex and gender, and so they should not be mixed up. To him, sex in this case refers to physical characteristics that differentiate male and female. Awopegba (2004) on the other hand, defines gender as a concept, a condition, a category, adjective and a component. It is a system of roles and relationships between men and women that are not determined by nature but by sound economic and political constructs. To Oakley (1996), "gender refers to socially constructed roles and socially learned behaviours and expectations associated with males and females". Thus, Maduewesi (2005), argues that women and men are biologically different, but all cultures interpret and elaborate these inherent biological differences into a set of social expectations about what behaviours and activities appropriate for them, and what rights, resources and even power they possess. Arising from the above situation, gender inequality arises where there is no equality of access or opportunities for both boys and girls. To this end, "gender equally" or "bridging the gender gap" in education involves not simply enrolling more girls in school, but also ensuring non-discriminatory education exposure for them in school and guaranteeing them equitable chances of success in learning

\section{The Constraints of Gender Inequality: The Nigerian Experience}

Over the years, efforts have been made to address gender inequality in access to basic education in the country. Governments at the State and Federal levels and other stakeholders in Nigeria's educational sector have attempted to address gender inequalities. Right from independence, basic education programmes in the country have expressed one form of concern or the other on the endemic gender inequality in access to education in the country. For example, the Universal Primary Education (UPE) and the Blue Print on Women Education developed by the Federal Ministry of Education in 1990 when UPE collapsed in 1984, were attempts at addressing gender inequality in access to education. These attempts made, were to identify a set of measures to achieve gender equity and participation in education at all level in the country (Abiola, 2006:171).

The key policy objectives of the Blue Print are as follows:

$\checkmark$ Increasing awareness for women education,

$\checkmark$ Pegging of legal age at first marriage at a minimum of 18 years for women

$\checkmark$ Enforcing legal provision of penalties for withdrawal of girls from schools for marriage.

$\checkmark$ Expanding facilities for "Second Chance" functional literacy education for adult women.

$\checkmark$ Providing education for women with special needs (Nomadic education and education for women in Pudah);

$\checkmark$ Establishment of women education centres by the Federal Ministry of Education in all the States of the Federation (Abiola, 2006)

Also, the provision of section I, sub-section 4(c) and 5(c) of the National Policy on Education (2004) are Federal Government's efforts at addressing gender inequality in access to basic education. Sub-section 4(c) provides that "Every Nigerian child shall have a right to equal educational opportunities irrespective of any real or imagined disabilities either according to his or her ability". Sub-section 5(c) emphasizes "the provision of equal access to educational opportunities for all citizens of the country at the primary, secondary and tertiary levels both inside and outside the formal school systems". In the same vain, in 1999, the Federal Government in an attempt to promote girl education towards attaining the Millennium Development Goals (MDGs), introduced the Universal Basic Education. Some of the main thrusts of the UBE Programme as listed in Salau (2001:3), as they relate to checking gender inequality in education, are:

a. To ensure that all children of 6 years and above get enrolled in primary schools and complete their education.

b. To contribute to a massive reduction of literacy and drop-out rate by making basic education free and compulsory for children and increasing the number of years of schooling for them.

c. To ensure that the hitherto underserved groups such as adult men and women, handicapped children, migrant workers and out-of-school youths have access to basic education.

d. To ensure equalizing access for both boys and girls, thus reducing gender disparities in school enrolment.

It needs to be said that in the past, governments have equally made efforts to address gender inequality in access to education in Nigeria through the promotion of women education. For instance, in September, 1986, the Federal Ministry of Education established a Women Education Unit charged with the following objectives:

a. Creating awareness in all citizens to the fact that equal opportunities should exist irrespective of age, gender, locality, creed or special states.

b. Provision of more educational opportunities for girls from primary to tertiary level, 
c. Provision of functional education for girls and women through skills such as sewing, cooking, typing, knitting, tie and dye etc and

d. Provision of functional education for girls and women in the field of science and technology (FME, 1986)

At the international sphere, the international community was committed to eliminating gender inequality in primary and secondary schooling by 2005 and to achieving equality through education, ten years later (UNESCO, 2003). Since Nigeria is a signatory to the 1990 Jomitiem Declaration of Education for all (EFA) by the year 2000 and a member of the group of E-9 nations committed to the total eradication of illiteracy, the resolutions from such convention are binding. The overall focus is access to quality education by all, and is expected to transcend enrolment of numbers to that which ensures the attainment of improved skills, knowledge and values for all recipients. The E-9 ("E" for Education and "9" for nine countries) initiative emphasizes education for all in nine high population developing countries like Bangladesh, Brazil, China, Egypt, India, Indonesia, Mexico, Nigeria and Pakistan. They account for half of the world's populations (3.2 billion), over 71 percent of the world's adult population and ore than half of its out-of-school children.

The initiative was launched in New Delhi, India, in 1993 and sponsored by UNESCO, UNICEF and UNFPA. The summit was able to mobilize high-level political support and financial and technical resources for primary education and literacy programmes in member countries towards the achievement of Education For All (EFA) goals. The education for all as stated in UNESCO (2002) and UNESCO (2003) is as follows:

a. Expanding and improving comprehensive early childhood care and education, especially for the most vulnerable and disadvantaged children.

b. Ensuring that by 2005, all children particularly girls, children in difficult circumstance and those belonging to ethnic minorities, have access to complete free and compulsory primary education of good quality.

c. Ensuring that learning needs of all young people and adults are met through equitable access to appropriate learning and life skills programmes.

d. Achieving $50 \%$ improvement in levels of adults literacy by 2015 , especially for women, and equitable access to basic and continuing education for all adults.

e. Eliminating gender disparities in primary and secondary education by 2005 , and achieving gender equality in education in 2015, with a focus on ensuring girl's full and equal access to and achievement in basic education of good equality.

However, the EFA Global Monitoring Report for 2002, Published by UNESCO (2002) reveals that at present, only three of the goals, that is, Universal Primary Education (UPE), adult literacy and gender parity have quantitative indicators making it possible to compare country progress. There is need to find out the extent to which Nigeria has realized these laudable goals so far. Report has shown that in Sub-Saharan Africa, only Rwanda and Seychelles are the countries that have achieved Universal Primary Education out of 30 countries in the sub-regions. Nigeria is one of the countries that are at serious risk of not achieving the goals.

On a positive note, there are a number of small civil society organizations in Nigeria that are implementing programmes on areas such as Female Gender Mutilation (FGM), Vesico Veginal Fistula (VVF), and early marriages, to provide support for widows and schooling for girls. However, the levels of progress vary considerable from one state to another. The progress in Cross River State is indicative of the potential for change if the federal government were to take a more assertive stance in planning, coordinating and realizing national programme of action for increased gender equality (APRM, 2008:3320).

In line with the above effort to address gender inequality in education, Cross River State has undertaken the following affirmative actions for women and girl-children education:

a. More schools have been built for children with some of the facilities

b. Free education from primary to secondary school level

c. Married women that dropped out of school due to early marriage or otherwise are given opportunity to continue with schooling at community-based education centres (APRM, 2008:333)

\section{Reasons for Gender Inequality in Educational System.}

Gender inequality in Nigeria's educational development may have been occasioned by the obvious discrimination against women in access to education in most parts of the world. Gender discrimination hinders access to education. According to Akulo (2009), in Nigeria, preference is given to the education of male children by some families and this gives rise to greater number and percentage of male children being enrolled in school than their female counterparts. To some people, especially in the rural areas, female education ends in the kitchen and therefore does not encourage their female children 
to have access to education. Tahir (1999) observed that in the analysis of gender unequally, women were unfairly represented at all levels of the educational system. This was supported by Enem (2008), who came to a similar conclusion and outlined the factors militating against women education to include the following.

a. Preference given to the education of males.

b. Early/child/forced marriages

c. Sex stereotyping in certain responsibilities/careers

d. Belief that women do not perpetuate the family nature

e. Poverty

f. Lack of proper education of parents, and

g. Early unwanted pregnancy/child labour/sexual harassment.

In Nigeria, education remains the basic constraints to women development. This is as a result of the preference for male education and anti-women education traces which are still visible in some parts of Nigeria, particularly the far North (Ainabor, Eregha and Ovbiagel, 2006:111). The consequent mental underdevelopment of women population according to Egonwan (2000), expresses itself in a double negative outcomes, namely, a few number of educated women and low educational equality or content of women education as most women shun courses in sciences, accounting and other fields that would equip them for work in the modern sector.

Socio-Cultural Factor: It needs to be observed that socio-cultural factor constitutes an impediment to women education in Nigeria, leading to gender inequality on our educational development. Various cultures restrict the role of women to domestic activities, such as keeping the home clean, bearing children, cooking food for the entire family members etc. The society as at today sees these roles as less important as they require less extensive formal education for one to be able to perform them. This unfortunate misconception has been a major obstacle to women development in Nigeria.

The School: This also contributes to gender inequality in education as it creates barriers to women's education, participation in messages contained in learning materials. To Longwe 91997), cited in Medel Anonevo (1997:82), "the content and orientation of education given to women constitutes a barrier". According to him, "empowerment involves the transformation and collective action by women to discard patriarchal belief and attitudes they have learned in the schools...... women are taught to accept the naturalness of male domination". These seemingly controversial views by Longwe, depict the school as traditionally responsible for perpetuating schooling for subordination hence, the source of women's powerlessness.

Parental Attitude: There is no doubt that the parental attitude towards the education of girl-children is responsible for the gender inequality in Nigeria's educational development. Ikpenwa (2005) has observed that in some parts of Nigeria, particularly in Igbo land, there exists a discriminatory tendency against the girl-child's education in favour of the boy-child education. Some parents are actually reluctant investing on education of girl-children since they do not see the wisdom of providing education for their daughters who would eventually get married and leave their families. Such parents out of ignorance regard the money spent on women education as a waste. However, the male child is regarded as the hair apparent and valuable asset to the family. This therefore makes parents to send their male children to schools without minding the amount of money invested in their education. Although some modern parents now send their female children to schools, many of them still prefer their male children to read professional courses in tertiary institutions instead of their female children.

Early Marriage: This also contributes to gender inequality in our educational system. According to Country Review Mission (CRM), early marriage for girls is sanctioned by cultural and religious beliefs which deprive girls of school to attain the skills needed for an empowering adult livelihood. The practice has contributed greatly to the lesser proportion of girls in school enrolments and the poor retention of girls in the school system, especially at the secondary and tertiary levels. In 2004, about 12 percent of girls between 10 and 14 years were married compared to 1 percent of boys of the same age. This situation contravenes the Federal Governments Child's Right Act 2003, which established 18 years as a minimum age for marriage. This shows that rights given in Federal Laws may not be adhered to at the level of the state (APRM, 2008:327).

High Cost of Living: List of living in Nigeria today has made it almost impossible for the average Nigerian families to train all their children in tertiary institutions. This therefore calls for parent's consideration of the cost implication of educating male and female children. Empirical evidence from Kanyuka (1992), cited in Ikpenwa (2005), revels that "it is really cheaper to train male children because of the discrepancy in their educational training cost which does not exist in the tuition fees but in the maintenance of female students. "it is naturally believed that female students spend more 
money on clothing, transportation, personal hygiene, shoes, secured accommodation and so on. To this end, economic factor remains a serious barrier to female education hence the gender inequality in our educational development.

Religious Belief: Is also one of the factors that contribute to gender inequality in Nigeria's educational development. Various religious leaders perceive women in different ways, as some believe that women should be confined to their houses (a situation close to false imprisonment). This therefore makes it difficult for young girls to acquire basic formal education. However, there are religious groups that do not encourage discriminatory practices against women education such as Christian religion. Thus, the educational gap, though closing, is still too wide for comfort in today's world and its expectations, more so as there is parity in the population of males and females in Nigeria.

\section{Recommendations}

In order to promote gender equality in Nigeria's educational development, the following recommendations are hereby made:

1. There is the need to discourage all forms of discriminatory practices against women education in Nigeria. This can be achieved if parents and other stakeholders are enlightened to accord equal value to both male and female children. In addition, all socio-cultural practices against equal access to education such as early marriage, exclusion of women, sex stereotyping in certain responsibilities/careers etc, must also be discouraged.

2. Government should as a matter of deliberate policy promote gender equality in access to education in Nigeria by insisting on the enrolment of certain percentage of girl children in schools. This is line with Affirmative Action that requires about 30 percent of women to be elected to political positions in African countries.

3. Since it is more expensive to train and maintain female children in schools, governments should augment the costs of parents upkeep of female students in tertiary institutions, by approving and implementing certain allowances or stipend for them. This will encourage parents to educate their female children.

4. In all institution of leaning in particular, male alone should not be allowed to hold executive position for instance where a man is the chief executive officer a woman should deputize.

5. Rather than sit on the fence, women themselves should develop negotiating and persuasive skills and rise to the challenge of assisting themselves in a competitive society like ours.

\section{Conclusion}

Despite the fact that the National Policy on Education and the 1999 Constitution of Federal Republic of Nigeria emphasize equal access to education by both males and females in Nigeria, there is evidence of gender inequality in our educational development. However, this paper has revealed that there is obvious inequality against girls in enrolment, attendance and completion rate in all levels of education in Nigeria, particularly in Northern parts of Nigeria owing to a variety of cultural and religious factors. Generally, women before the last three decades have suffered discriminatory practices in the field of education hence the gender inequality in our educational development. It concluded that despite the efforts of both the Federal and State governments in this regard, the gap between males and females in access is still too wide for comfort in today's world and its expectations. This, the paper feels is the greatest challenge confronting and hindering the effective empowerment of women for sustainable development in Nigeria.

\section{References}

Abiola, O. (2006). Gender consciousness in special needs education" in contemporary issues in special needs education Ozoji, E. D. et al (eds) Jos: Deka publications.

African peer review mechanism (2008). Country review report No. 8 Federal Republic of Nigeria.

Ainabor, A. E. Ainabor, S. A. \& Ehimi, O. C. (2009), "gender equality. A panacea for good governance and socio-economic development in Nigeria, A paper preseentd at the $8^{\text {th }}$ National Conferences of National association for research development (NARD), Auchi Polytechnic, Auchi, from $5^{\text {th }}$ to $9^{\text {th }}$ October, 2009.

Ainabor A. E, Eregha, E. E. \& Ovbiagele, A.I.O (2006). Women Education in Nigeria: Implications for Socio-Economic Development "Journal of academics

Ainabor A.R. \& Ovbiagele, A. I.O (2007). "Implications of women education for poverty alleviation in Nigeria", Journal of academics 2(2), p.43.

Akudo, F.U. (2009). Implementation of access to universal basic education in Nigeria. In emergent issues in Universal Basic Education Programme in Nigeria, N. Ada, B. U. Maduewesi \& c. I Ihebereme (Eds), Lagos: West and Solomon publishing co Itd. 
Ametefe, G.T.D. \& Ametefe, M.D. (2007), Re-positioning women education for national development in the 21th century, "Journal of research development, 8(5), p. 68

Awopegba, P.O (2004). "the catalytic role of women in the national development". In democratic governance and development management in Nigeria fourth republic, 1999 2003, I. B. Bello Imam and Mike Obandan: centre for local government and rural development studies.

Awopegba P. O, \& Orubu, C.O (2003), Structural shifts in gender access to education in Nigeria for development and the universal basic education programme, Monograph submitted to the reseach development, Ncema, Ibadan.

Egibbwab, J.A (2000), Public Policy anablysis: concepts and applications Benin city: Resyin (Nig) company.

Enem, F.O (2008). "Reforms in basic education as a means for the attainment of millennium development goals in Nigeria" in Nworgu, B. G. (ed), education reforms and the attainment of millennium goals: the Nigeria experience, Nsukka: university trust publishers.

Federal Ministry of Education (1986). Women affairs branch, Lagos: Federal Government Press.

Federal Republic of Nigeria (2004) National Policy on Education $4^{\text {th }}$ edition, Lagos: NERDC press.

Ikpewa, J. N (2005). Improving quality of women education in Nigeria, journal of qualitative education, 1(3) p.9.

Miaduewesi, E. J. (2005). Benchmarks \& global trends in education, Benin city: Dasylva influence enterprises.

Medel Anonuevo, C. (1997), learning gender justice: challenges of adult learning in the $21^{\text {st }}$ century, adult education and development, No. 49 pp. $81 \& 90$

Oakley, A. (1996), Sex, gender and society, England: Gower publishing company limited.

Ogboagu, A. R. (2009). "Universal Basic Education: a catalyst to improve human capital and national development in Nigeria" in emergent issues in Universal Basic Education Programme in Nigeria (N. Ada, A.U Maduewesi \& C. I. Ihebereme (eds) Onitsha: West and Solomon Publishing Co. Itd.

Oke, G. G. (2005), Cultural and Curriculum perspectives of gender inequality in technology education. In Curriculum issues in contemporary education. Oriafor, S. O Edozie, G.C. \& Ezeh, D. N. (eds) Benin City: Dasylva influence.

Salau, M. O. (2001), implementation of Universal Basic Education Scheme of the junior secondary school level: issues, problem and prospects, "Nigerian Journal of curriculum studies (CON), 8 (1).

Tahir, g. (1999). Women education for active participation in the next millennium, journal of women in colleges of education (WICE).

UNESCO (2002), Education for all: is the world on track? Efa global monitoring reports, paris: graph print.

UNESCO (2003), Gender and Education for all: the leap to equality. A summary report, UNESCO. 